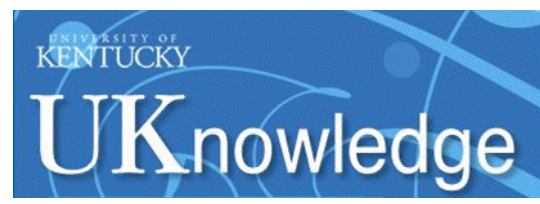

University of Kentucky

UKnowledge

\title{
Assessing Genetic Diversity of Elymus sibiricus (Poaceae: Triticeae) Populations from Qinghai-Tibet Plateau by ISSR Markers
}

Xiao Ma

Sichuan Agricultural University, China

Xinquan Zhang

Sichuan Agricultural University, China

Yonghong Zhou

Sichuan Agricultural University, China

Shiqie Bai

Sichuan Agricultural University, China

Follow this and additional works at: https://uknowledge.uky.edu/igc

Part of the Plant Sciences Commons, and the Soil Science Commons

This document is available at https://uknowledge.uky.edu/igc/21/1-5/30

The XXI International Grassland Congress / VIII International Rangeland Congress took place in Hohhot, China from June 29 through July 5, 2008.

Proceedings edited by Organizing Committee of 2008 IGC/IRC Conference Published by Guangdong People's Publishing House

This Event is brought to you for free and open access by the Plant and Soil Sciences at UKnowledge. It has been accepted for inclusion in International Grassland Congress Proceedings by an authorized administrator of UKnowledge. For more information, please contact UKnowledge@lsv.uky.edu. 


\section{Assessing genetic diversity of Elymus sibiricus (Poaceae : Triticeae) populations from Qinghai- Tibet Plateau by ISSR markers}

Xiao Ma, Xin-Quan Zhang, Yong-Hong Zhou and Shi-Qie Bai

Department of Grassland Science, College of Animal Science and Technology, Sichuan A gricultural University, Ya'an, 625014,PRChina,E-mail.maroar@163com

Key words : Triticeae ; Elymus sibiricus ; ISSRs ; Population structure ; Diversity

Introduction Elymus sibiricus L. (Siberian wildrye) is a perennial, self-pollinating and allotetraploid grass indigenous to Northern Asia, possessing the StH genome (Dewey, 1974). In the subalpine meadows with less than 4000m altitude in Qinghai-Tibet Plateau, E. sibiricus usually serves as an important forage species . Climate warming, loss of habit by deforestation and excessive gazing at high altitude pastures in the entire Qinghai-Tibet Plateau region now begin to threaten its survival. In the present study, we employed ISSR markers to investigate the genetic structure of natural E. sibiricus populations from southeast of Qinghai-Tibet Plateau.

Materials and methods Leaves of 93 individuals of E. sibiricus were collected from eight populations in southeast of QinghaiTibet Plateau, Sichuan Province, China. Individuals generally $5-10 \mathrm{~m}$ apart from one another were sampled randomly within each population. Genomic DNA was extracted using the CTAB method .100 primers (University of British Columbia primer set 9) were first screened for PCR amplification. Eighteen ISSR primers (UBC \# 807,808,811,813,818,825,835,836,840, $842,844,845,853,856,857,864,873$ and 880) that generated clear , reproducible banding patterns were selected for further analysis. Polymerase chain reaction (PCR) and electrophoresis were carried out as described in Carvalho et al . (2005) . Unequivocally scorable and consistently reproducible amplified ISSR bands were scored as present (1) and absent (0), each of which was treated as an independent character regardless of its intensity. The genetic structure of studied populations were calculated by POPGENE, Arlequin and TFPGA software .

Results Of the 100 primers screened, 13 produced highly reproducible ISSR bands . Using these primers, 193 discernible DNA fragments were generated with $149(77.2 \%)$ being polymorphic, indicating considerable genetic variation at the species level . In contrast, there were relatively low levels of polymorphism at the population level with the percentage of polymorphic bands (PPB) ranging from $44.04 \%$ to $54.92 \%$. The mean gene diversity ( $\mathrm{HE}_{\mathrm{E}}$ ) was estimated to be 0.181 within populations (range 0.164 to 0.200 ), and 0.274 at the species level . A high level of genetic differentiation among populations was detected based on Nei's genetic diversity analysis (33.1\%), Shannon's index analysis (34.5\%), Bayesian method (33 .2\%) and AMOVA analysis $(42.5 \%)$. No significant statistical differences (analysis of molecular variance [ AMOVA], P=0 .08) in ISSR variation w as found between regions. However, among populations (42.5\% of the variance) and within populations (57.5\% of the variance), there were significant differences $(\mathrm{P}<0.001)$. Populations shared high levels of genetic identity This pattern of genetic variation was different from that reported for most of inbreeding Triticeae species reported .

Conclusions The high degree of genetic variation found in present study is probably accounted for the wide distribution of $E$. sibiricus. Owing to the fact that the eight population studied are closed located, the possible explanation for the higher intrapopulation variation patters revealed in this study is that these studied populations were collected from near the central or founding population .

\section{Reference}

Carvalho, A ., Matos, M ., Lima-Brito , J ., Guedes-Pinto , H . \& C . Benito (2005) . DNA fingerprint of F 1 interspecific hybrids from the Triticeae tribe using ISSRs. Euphytica, $143,93-99$. 